\title{
Aktualisasi Diri Ki Seno Nugroho: Tinjauan Pemenuhan Kebutuhan dalam Teori Motivasi Abraham H. Maslow
}

\author{
Elisha Orcarus Allasso \\ Jurusan Pedalangan, Fakultas Seni Pertunjukan, Institut Seni Indonesia Yogyakarta \\ Email: elishaorcarus@gmail.com
}

\begin{abstract}
The purpose of this research is to reveal self-actualization Ki Seno Nugroho as a dalang by way of examining his motivation in meeting the level of needs. Maslow's motivational theory, especially regarding the fulfillment of needs used to analyze self-actualization Ki Seno Nugroho. This research uses ethnographic method in describing field observation and interview result. From the analysis results obtained conclusion self-actualization Ki Seno Nugroho is the peak of the process of fulfillment of the needs level. Achievement of self actualization needs begins with knowing the talent and potential. Awareness of the talent possessed dreams as the highest needs and to achieve them must go through a long process. Ki Seno Nugroho has succeeded in actualizing himself and fulfilling his dream through his talent. After he succeeded in realizing his dreams in his youth to become a puppeteer favored by the public, his next dream is to keep fans and prepare the next generation in order to preserve the Javanese culture especially the puppet show. The attainment of self-actualization through the level of fulfillment of needs will continue and develop as long as it lives.
\end{abstract}

Keywords: Seno Nugroho; self-actualization; needs fulfillment; mastermind; motivation

\begin{abstract}
Abstrak
Tujuan dari penelitian ini adalah untuk mengungkap aktualisasi diri Ki Seno Nugroho sebagai seorang dalang dengan cara menelisik motivasinya dalam memenuhi tingkat kebutuhan. Teori motivasi Maslow khususnya mengenai pemenuhan kebutuhan digunakan untuk menganalisis aktualisasi diri Ki Seno Nugroho. Penelitian ini menggunakan metode etnografi dalam mendiskripsikan pengamatan lapangan dan hasil wawancara. Dari hasil analisis didapat kesimpulan aktualisasi diri Ki Seno Nugroho adalah puncak dari proses pemenuhan tingkat kebutuhan. Pencapaian kebutuhan aktualisasi diri diawali dengan mengetahui bakat dan potensi yang dimiliki. Kesadaran mengenai bakat yang dimiliki melahirkan impian sebagai kebutuhan tertinggi dan untuk mencapainya harus melalui proses panjang. Ki Seno Nugroho telah berhasil mengaktualisasikan diri dan mewujudkan impiannya melalui bakat yang dimilikinya. Setelah ia berhasil mewujudkan impiannya di masa muda yaitu menjadi dalang yang digemari oleh masyarakat, impian selanjutnya adalah mempertahankan penggemar dan mempersiapkan generasi berikutnya agar dapat melestarikan budaya Jawa terutama pertunjukan wayang. Pencapaian aktualisasi diri
\end{abstract}


melalui tingkat pemenuhan kebutuhan akan terus berlangsung dan berkembang selama ia hidup.

Kata kunci: Seno Nugroho; aktualisasi diri; pemenuhan kebutuhan; dalang; motivasi

\section{Pendahuluan}

Pada tahun 2015 Seno Nugroho (selanjutnya disebut SN) adalah dalang yang memiliki frekuensi tanggapan ('mempergelarkan wayang atas permintaan orang atau institusi dan dibayar') cukup tinggi di Yogyakarta. Berdasarkan jadwal milik Tusiyo, pengrawit SN, tercatat dari bulan Agustus sampai dengan November 2015, frekuensi mendalang SN sebagai berikut: pada bulan Agustus tahun 2015 sebanyak 22 kali, Sepetember 11 kali, Oktober 12 kali dan November 15 kali dengan tarif tanggapan berkisar 30 hingga 35 juta rupiah. Di bulan Agustus 2015, saat pertunjukan wayang digelar cukup banyak oleh penanggap, dalang Yogyakarta lainnya rata-rata memiliki tarif tanggapan lebih rendah yaitu berkisar 7-15 juta rupiah dan memiliki 2-6 kali tanggapan saja. Di jaman global ini, seorang dalang di Yogyakarta cukup sulit untuk mendapatkan frekuensi tanggapan mendalang di atas 10 kali selama satu bulan dengan tarif yang tinggi di setiap pergelaran. Oleh karena itu, adalah suatu prestasi bagi SN karena memiliki frekuensi pertunjukan di atas 10 kali selama empat bulan berturut-turut dengan tarif setiap tanggapan lebih dari 30 juta.

Selain memiliki banyak penanggap, SN memiliki banyak penggemar yang tersebar di Yogyakarta. Sejak tahun 2013, sebagian dari penggemarnya membuat suatu komunitas yang disebut dengan PWKS (Pecinta Wayang Ki Seno Nugroho). Tujuan dari PWKS adalah membantu mendapatkan informasi pertunjukan juga transportasi menuju lokasi pertunjukan. PWKS menjadi wadah bagi para penggemar $\mathrm{SN}$ yang ingin terus mengikuti pergelarannya. Mereka melakukan hal tersebut berdasarkan inisiatif kelompok.

Bukti bahwa SN adalah dalang yang digemari masyarakat Yogyakarta saat ini, dapat dilacak melalui persebaran lokasi pentas dan padatnya penonton dalam setiap pertunjukannya. Fenomena SN sebagai dalang yang digemari oleh masyarakat masa kini sebenarnya adalah hal yang tidak lazim.
Dalam kehidupan sehari-hari, masyarakat masa kini lebih fokus untuk melakukan pekerjaan di siang hari dan beristirahat di malam hari. Hiburan harian yang dibutuhkan masyarakat masa kini adalah hiburan yang ringan dan mudah dijangkau. Oleh karena itu dapat dikatakan pertunjukan wayang saat ini sulit mendapatkan tempat di hati masyarakat. Selain karena pertunjukannya dilakukan dalam satu malam, masyarakat masa kini juga sangat miskin pengetahuan akan pertunjukan wayang maupun bahasanya. Kondisi yang demikian itu sejalan apa yang dikatakan oleh Ahimsa-Putra (2000: 34) berikut ini: “...karena adanya tuntutan masyarakat masa kini, masyarakat modern lebih menginginkan realisme daripada hal-hal yang lebih simbolik sifatnya ...tidak banyak lagi orang yang tertarik untuk datang ke tempat-tempat pertunjukan untuk menonton secara langsung".

Namun demikian ada fenomena yang menarik dalam kondisi masyarakat seperti dipaparkan di atas. Di tengah masyarakat yang menginginkan sesuatu yang serba cepat, serba mudah, serba singkat, tidak perlu terlalu berpikir tentang simbol, dan malas bergerak, SN adalah seorang dalang yang berhasil membuat banyak orang datang dan menonton pergelarannya. SN juga memiliki penggemar dan penanggap yang setia menyaksikan pertunjukan wayang kulit sajiannya. Berdasarkan hal tersebut dapat diasumsikan bahwa SN adalah dalang yang memiliki daya tarik cukup besar di Yogyakarta saat ini.

Kemampuan SN untuk mendapatkan hati masyarakat rupa-rupanya disebabkan oleh usaha SN dalam mengaktualisasikan dirinya sebagai seorang dalang. SN berproses dan berstrategi untuk mewujudkan keinginannya tersebut. Jika dilihat dari penghasilannya, SN termasuk berpenghasilan tinggi. Dahulu, seorang dalang memiliki upah tidak sampai 5 kilogram beras dalam satu pergelaran (Soedarsono 87th). Kini jika dihitung dengan beras, berarti upah SN mendalang mencapai sekitar 1 ton beras. Perubahan tingkat upah tersebut tidak terjadi begitu saja, namun perlu ada keinginan besar untuk 
berproses dan mencapainya. Pencapaian angka tinggi pada tingkat upah, frekuensi mendalang, maupun penggemar, merupakan keberhasilan SN dalam memenuhi kebutuhan yang bertahap untuk mencapai keberhasilan. Strategi SN dalam mewujudkan berbagai kebutuhan hidup dan mengaktualisasikan diri sebagai figur dalang yang disukai masyarakat akan dilacak melalui penelitian ini.

Penelitian ini bertujuan mengungkap aktualisasi diri SN, yang secara rinci diperoleh dengan cara menelisik motivasi $\mathrm{SN}$ dalam memenuhi tingkat kebutuhan sampai pada tahap aktualisasi diri sebagai seorang dalang. Hasil penelitian dengan pendekatan ilmu psikologi ini diharapkan dapat memberikan wawasan lebih luas bagi ilmu pedalangan mengenai motivasi pemenuhan kebutuhan seorang dalang. Selain itu penelitian ini diharapkan dapat memberikan inspirasi bagi para calon dalang untuk mengolah potensi dalam dirinya. Secara lebih khusus dalam hubungannya dengan mata kuliah pengetahuan pedalangan maupun manajemen seni pedalangan, penelitian ini bermanfaat untuk menambah wawasan mengenai proses motivasi seorang dalang menjadi sukses. Dengan demikian, penelitian ini dapat memotivasi mahasiswa dalam memenuhi kebutuhan aktualisasi diri dan mewujudkan impian dengan berprofesi menjadi seorang dalang ataupun pekerjaan lain sesuai dengan potensi yang dimiliki.

\section{Konsep Tingkat-Tingkat Pemenuhan Kebutuhan dalam Teori Motivasi Maslow}

Teori motivasi Maslow (1994) dipakai sebagai penuntun analisis penelitian ini. Teori tersebut digunakan untuk menemukan motivasi SN dalam memenuhi kebutuhan dan mengaktualisasikan diri. Maslow (1994: 31) berasumsi bahwa manusia tidak berhenti pada satu keinginan. Asumsi inilah yang menggiringnya untuk mengatakan bahwa terjadinya pemenuhan kebutuhan tingkat puncak berawal dari bermacam-macam keinginan manusia. Setelah kebutuhan dasar terpenuhi maka akan muncul kebutuhan-kebutuhan berikutnya, begitu seterusnya hingga mencapai puncak kebutuhan manusia yaitu aktualisasi diri.

Maslow (1994: 43-57) membuat klasifikasi kebutuhan dalam suatu hirarki yang digambarkan dalam bentuk piramida lima tingkat kebutuhan. Kebutuhan pertama adalah kebutuhan dasar fisiologis (physiological needs). Kebutuhan fisiologis mencakup berbagai kesenangan panca indra (rasa, bau, gelitik, belaian). Maslow (1994: 4445) mengungkapkan, seorang yang ingin makan bisa jadi karena lebih mencari kesenangan hidup dari pada pemenuhan vitamin dan protein. Di sisi lain, seseorang memuaskan laparnya dengan minum dan merokok. Pada intinya Maslow berasumsi bahwa manusia memenuhi rasa lapar karena kekurangan zat dalam tubuh dan di sisi lain karena selera. Berikutnya Maslow (1994: 46-47) berpendapat bahwa manusia akan hidup demi makanan jika tidak ada makanan, sebaliknya akan berbeda dengan manusia yang setiap hari berkelimpahan makanan dan perutnya selalu terisi. Jika kebutuhan fisiologisnya terpenuhi, manusia akan memenuhi kebutuhan lainnya yang lebih bersifat sosial. Tingkat pemenuhan kebutuhan yang kedua adalah kebutuhan akan keselamatan atau rasa aman (neeed of security). Maslow (1994: 47) mengatakan jika kebutuhan fisiologis telah terpenuhi, maka kebutuhan baru berikutnya yaitu kebutuhan akan keselamatan (keamanan, kemantapan, ketergantungan, perlindungan, bebas dari rasa takut, cemas dan kekalutan, kebutuhan akan struktur, ketertiban, hukum, batas-batas, dan sebagainya). Umumnya orang dewasa tidak merasa hidupnya terancam bahaya. Maslow (1994: 51) mengungkapkan, kebutuhan akan keselamatan berikutnya lebih pada fenomena seperti keinginan akan kedudukan yang tetap dalam pekerjaan agar terus terlindungi, atau keinginan untuk memiliki rekening tabungan dan membuat asuransi. Kebutuhan akan keamanan ini akan kembali aktif dan dominan saat keadaaan darurat seperti perang, wabah penyakit, bencana alam, gelombang kejahatan, kekacauan sosial dan lain sebagainya. Akhirnya manusia akan memagari dan membuat antisipasi dengan berbagai aturan dan norma dengan upacara ataupun hukum dalam kepercayaan yang dianut. Mereka mencoba mengatur kehidupannya sedemikian rupa agar hal-hal seperti ini tidak terjadi (Maslow 1994: 52-53). Tingkat pemenuhan kebutuhan yang ketiga yaitu kebutuhan akan rasa cinta dan rasa memiliki (need for love and belonginess). Maslow (1994: 53) mengatakan, manusia yang telah 
memenuhi kebutuhan fisiologis dan rasa aman, akan mulai membutuhkan rasa cinta, kasih, dan rasa memiliki. Mereka butuh diakui keberadaannya dalam keluarga, suatu klan, kelompok, teman, wilayah, ataupun lingkungan tetangga. Saat manusia lapar atau merasa dirinya berada dalam bahaya, ia bisa mencemooh cinta sebagai sesuatu yang tidak nyata. Namun saat kebutuhan lapar dan rasa aman terpenuhi orang ini akan mulai merasakan perihnya rasa kesepian, pengucilan sosial dan penolakan. Kebutuhan akan cinta dan rasa memiliki akan mendorong individu untuk membangun hubungan afektif dengan orang lain, baik dalam keluarga, lingkungan pergaulan atau dalam kelompok. Maslow (1994: 54) menguraikan mengenai keadaan yang biasa terjadi pada manusia yaitu membuat kelompok persahabatan dengan kesamaan yang dimiliki untuk bertahan dari ancaman. Kebutuhan akan rasa harga diri (need for self esteem) merupakan pemenuhan tingkat kebutuhan yang keempat. Maslow (1994: 55) membagi kebutuhan akan rasa harga diri menjadi dua, yakni rasa menghargai diri sendiri dan pengakuan dari orang lain. Rasa menghargai diri sendiri berupa keinginan akan kekuatan, prestasi, kecukupan, keunggulan, kepercayaan pada diri sendiri dalam menghadapi dunia serta kemerdekaan dan kebebasan. Sedangkan yang dimaksud dengan harga diri berdasarkan pengakuan dari orang lain adalah hasrat akan nama baik atau gengsi, prestise (penghargaan dari orang lain), status, ketenaran, kemuliaan, dominasi, pengakuan perhatian, martabat dan apresiasi. Maslow (1994: 56) juga menuliskan bahwa pemenuhan akan kebutuhan ini membawa perasaan percaya pada diri sendiri, juga pada nilai, dan kekuatan. Namun rintangan menuju pemenuhan kebutuhan ini akan menimbulkan perasaan rendah diri, lemah, dan tak berdaya. Maslow menekankan, harga diri yang paling sehat dilandaskan pada penghargaan yang diperoleh dari orang lain bukan dari ketenaran. Tingkat pemenuhan kebutuhan yang kelima adalah kebutuhan akan aktualisasi diri (need for self actualization). Maslow (1994: 56) meletakkan kebutuhan aktualisasi diri sebagai kebutuhan manusia yang paling tinggi dalam hierarki kebutuhan. Manusia tidak akan berhenti memenuhi kebutuhan. Kegelisahan baru untuk memenuhi kebutuhan akan terus berkembang kecuali jika orang itu melakukan apa yang secara individual sesuai baginya seperti menjadi seorang atlit, menjadi ibu yang ideal, atau terus melukis. Berikutnya Maslow (1994: 163) mengungkapkan, orang yang berada pada tingkat perkembangan motivasional aktualisasi diri, dapat dikatakan tindakan dan kreasi mereka sangat spontan, penuh siasat terbuka, membeberkan diri dan disertai pertimbangan. Perwujudan diri atau aktualisasi diri dikatakan oleh Maslow (1994: 164) merupakan sesuatu yang tumbuh dari dalam, dari sesuatu yang telah ada dalam organisme itu, atau lebih tepat lagi, dari sesuatu yang merupakan organisme itu sendiri. Individu harus dapat memenuhi keempat kebutuhan di tingkat sebelumnya untuk mencapai aktualisasi diri. Maslow (1994: 164) juga mengungkapkan, aktualisasi diri lebih bermotivasi pada pertumbuhan bukan kekurangan. Orang yang mencoba mengaktualisasikan diri akan memecahkan persoalan motivasional kecil, dengan demikian mereka akan menyadari dan dapat menghadapi dengan spontanitasnya. Dalam mengatasi permasalahan, mereka lebih memilih untuk terus mencoba dari pada tidak mencoba.

Teori lima tingkat pemenuhan kebutuhan Maslow dalam penelitian ini akan diimplementasikan dalam kepribadiaan seorang dalang. Tentu implementasinya disesuaikan dengan kebudayaan yang melekat pada diri dalang tersebut. Misalnya dalam pemenuhan dasar fisiologis, seorang dalang tidak memenuhi rasa lapar berupa makanan. Artinya, rasa lapar dalang bukan sekedar kekurangan vitamin maupun protein, melainkan lebih kepada kesenangan kebutuhan indrawi yang berkaitan dengan perilaku dalang. Demikian pula mengenai tingkat kebutuhan lainnya yang akan dianalisis dan disesuaikan dengan kebiasaan subjek sebagai dalang. Akhirnya, dalam penelitian ini kebutuhan aktualisasi diri subjek akan dilacak berdasarkan proses dan perilakunya sebagai dalang saat memenuhi setiap tingkat kebutuhan.

\section{Pencapaian Aktualisasi Diri Seno Nugroho Berdasarkan Proses Pemenuhan Kebutuhan Bertingkat Dalam Teori Motivasi Maslow}

Seperti telah dikemukakan di depan, pemenuh an kebutuhan subjek (dalam penelitian ini adalah sang dalang SN) dianalisis menggunakan pemikiran 
Maslow terhadap kehidupan subjek sebagai seorang dalang. Maslow (1994: 46-47) mengatakan bahwa manusia akan hidup demi makanan. Subjek pernah mengalami tingkatan hidup demi makanan, namun yang dimaksud makanan bukan berupa protein atau vitamin namun pemenuhan kebutuhan hidup. Subjek mengalami masa sulit memenuhi kebutuhan saat ayahnya meninggal dunia. Ia harus membantu ibunya memenuhi kebutuhan hidup, dan pada saat itulah pemenuhan dasar fisiologis subjek sangat dominan. Subjek mengatakan, ia harus mencari penghasilan agar dapat membeli rokok. Segala usaha yang dilakukan pada saat itu bertujuan untuk mencari uang dan mendapatkan pekerjaan sehingga dapat memenuhi kebutuhan dasar fisiologisnya. Di masa itu, subjek memenuhi kebutuhan indrawinya dengan berlatih keras, berpuasa dan melakukan kegiatan spiritual. Subjek merasakan kepuasan indrawi jika melakukannya. Baginya, berlatih keras, berpuasa dan melakukan kegiatan spiritual adalah upayanya dalam mengolah diri dan mencapai tujuannya.

Setelah subjek dapat mendalang dengan baik dan memiliki banyak jadwal tanggapan, pemenuhan kebutuhan dasar fisiologis yang utama seperti kebutuhan bertahan hidup dan membeli rokok kini bukan lagi menjadi masalah untuknya. Ia telah mampu membeli rumah dan berbagai perabotannya juga kendaraan yang harganya tidak murah. Kemampuan subjek membeli segala macam kebutuhan saat ini bukan berarti ia sudah tidak memiliki kebutuhan dasar fisiologis.

Maslow (1994: 44-45) mengungkapkan, seorang yang ingin makan bisa jadi karena lebih mencari kesenangan hidup dari pada pemenuhan vitamin dan protein. Perilaku subjek dalam memenuhi kebutuhan indrawi kini dapat dikatakan lebih bertujuan untuk mencari kesenangan hidup. Pemenuhan kebutuhan tersebut lebih nampak pada kegiatannya menikmati hidup dan melakukan perbuatan kesukaannya. Waktu luang yang subjek miliki biasa digunakan untuk menonton pertunjukan wayang, berdiskusi mengenai pertunjukan wayang, atau membeli wayang baru lalu mengamatinya dan memainkannya. Subjek juga menikmati hidupnya dengan pergi ke suatu tempat, bersepeda, atau juga merawat kendaraan seperti mencuci motor dan berbagai kegiatan lainnya yang ia sukai. Dari berbagai kegiatan yang memberi kepuasan indrawinya, yang paling dominan adalah kegiatan yang berkenaan dengan wayang, dunia pedalangan, dan segala yang terkait di dalamnya. Telah dikatakan di depan bahwa pemenuhan rasa lapar seorang dalang bukan sekedar pada pemenuhan makanan melainkan lebih mengarah kepada kepuasan indrawi bersama dengan wayang dan segala hal yang terkait dengannya.

Selanjutnya Maslow (1994: 46-47) mengungkapkan, jika kebutuhan fisiologisnya terpenuhi, maka pemenuhan kebutuhan berikutnya adalah kebutuhan akan keselamatan (keamanan, kemantapan, ketergantungan, perlindungan, bebas dari rasa takut, cemas dan kekalutan, dan sebagainya). Manusia yang telah banyak menghabiskan waktunya dengan berbagai hal yang ia gemari, tanpa disadari ia akan membuat aturan-aturan untuk dirinya sendiri agar hidupnya tidak terancam, dan ia akan mempertahankan apa yang menjadi kegemarannya. Di awal karirnya, subjek melakukan pekerjaan sebagai dalang dengan tujuan untuk memenuhi kebutuhan hidup. Namun seiring dengan pemahaman subjek, ia mulai merasakan bahwa kebudayaan wayang semakin melekat dalam dirinya. Dengan demikian, subjek melakukan berbagai perilaku yang diyakini dapat menjadi cara agar ia dapat berprofesi sebagai dalang yang diinginkan masyarakat. Perilaku tersebut antara lain seperti belajar dengan sungguh-sungguh, mengambil berbagai kesempatan yang ada, dan sebagainya. Pemenuhan kebutuhan rasa aman di awal karir subjek adalah menghindari berbagai ancaman yang membuat impiannya runtuh.

Ketika karir subjek sudah berada pada titik aman, akhirnya ia mencoba mengatur kehidupannya sedemikian rupa agar pekerjaannya bertahan. Maslow (1994: 51) mengungkapkan bahwa kebutuhan akan keselamatan berikutnya lebih pada fenomena seperti keinginan akan kedudukan yang tetap dalam pekerjaan, agar ia terus terlindungi. Subjek telah berhasil meraih pekerjaan mendalang sebagai sumber utama pemenuhan kebutuhannya. Selanjutnya, pemenuhan kebutuhan akan rasa aman subjek adalah mempertahankan pekerjaannya. Subjek memberitahukan bahwa hal yang menjadi ancaman besar baginya yaitu ditinggalkan penggemar. Maka subjek akan membuat antisipasi untuk menghindari ancaman tersebut antara lain: belajar tekun mendalami apa yang menjadi 
bidang keahliannya dan menghargai pengalaman hidup, memiliki banyak dukungan dari orang lain, mempertahankan kualitas pertunjukan, dan sebagainya. Akhirnya antisipasi yang dilakukannya lebih bertujuan untuk selalu mendapatkan hati penggemarnya.

Subjek memiliki banyak penggemar, namun di sisi lain tidak sedikit pula ejekan-ejekan atau ungkapan kebencian yang diberikan untuk pertunjukannya. Menurutnya, ia sudah sangat terbiasa dicemooh atau dibenci, namun hal itu tidak mengganggunya. Ia telah membuktikan dengan keberhasilannya bertahan mendalang dengan penggemar yang cukup banyak selama kurang lebih dua puluh tahun. Berapapun banyaknya orang yang membencinya tidak menjadi masalah selama ia memiliki penggemar. Impian subjek tidak akan runtuh selama masih ada orang-orang yang menantikan pertunjukannya. Akhirnya dapat diketahui bahwa pemenuhan kebutuhan rasa aman ini mengarahkan subjek pada pencapaian tujuan. Ancaman bagi subjek terutama kehilangan penggemar adalah hal yang meruntuhkan impiannya. Kini subjek masih memiliki banyak penggemar, oleh karena itu tidak ada ancaman yang sangat mengganggunya saat ini.

Pemenuhan kebutuhan akan rasa aman mengantarkan subjek untuk memenuhi kebutuhan berikutnya. Maslow (1994: 53) mengungkapkan saat manusia lapar atau merasa dirinya berada dalam bahaya, ia bisa mencemooh cinta sebagai sesuatu yang tidak nyata. Namun saat kebutuhan lapar dan rasa aman terpenuhi, orang ini akan mulai merasakan perihnya rasa kesepian, pengucilan sosial dan penolakan serta adanya ancaman tanpa dukungan orang lain. Subjek dapat mengantisipasi datangnya ancaman dalam pekerjaan dengan cara mendapatkan dukungan dari orang lain. Dengan dukungan dari orang lain, maka subjek akan lebih mudah dalam proses pencapaian tujuan.

Kebutuhan akan cinta dan rasa memiliki akan mendorong individu untuk membangun hubungan afektif dengan orang lain, baik dalam keluarga, lingkungan pergaulan atau dalam kelompok. Pertama-tama, subjek memenuhi kebutuhan akan cinta dan rasa memiliki melalui hubungan afektif yang ia bangun dengan keluarganya. Dalam melakukan hubungan afektif dengan keluarga, rupa-rupanya tidak dicapai dengan mudah. Di kala subjek memiliki jadwal pertunjukan yang padat maka ia tidak memiliki banyak waktu untuk membangun hubungan afektif dengan keluarganya. Subjek harus membuat acara khusus seperti spontanitas untuk rekreasi atau pergi bersama keluarga ke suatu tempat. Subjek mengatakan bahwa ia sangat mencintai anakanaknya, namun keterbatasan waktu membuat subjek tidak memberikan kedekatan yang berlebihan. Hal tersebut dilakukan agar anak-anaknya tidak terlalu merasa kesepian jika subjek tidak ada di rumah. Di sisi lain, subjek memperhatikan masa depan anak-anaknya. Anak-anak dan istri subjek memahami cara subjek mencintai mereka. Maka mereka juga memberikan dukungan sepenuhnya pada subjek untuk menekuni pekerjaannya.

Saat setiap anggota keluarga memiliki kesibukan masing-masing, ia akan memenuhi kebutuhan tersebut melalui kelompok kerja, lingkungan sekitar, ataupun para penggemar. Ia memenuhi kebutuhan akan rasa cinta dan rasa memiliki dengan membangun hubungan afektif dengan mereka. Dengan demikian subjek mendapatkan dukungan sepenuhnya dari orangorang tersebut untuk pencapaian tujuan. Bagi seorang dalang, rasa cinta dan rasa memiliki bukan hanya diwujudkan pada hubungan afektifnya dengan orang lain. Ia juga menuangkannya pada kegemaran dan benda kesayangannya. Sebagai seorang dalang, rasa memiliki terhadap wayang dan berbagai hal yang terkait juga sangat tinggi. Ia mencintai wayang sebagai bagian dari dirinya. Disadari atau tidak, pemenuhan kebutuhan akan rasa cinta dan rasa memiliki mendorong subjek pada pemenuhan akan harga diri. Berbagai dukungan dari orang di sekitarnya memberikan penilaian yang baik terhadap subjek. Demikian pula penuangan rasa cinta dan rasa memiliki terhadap wayang juga mempengaruhi penilaian terhadap subjek di atas panggung. Jajaran wayang dengan warna perada emas dan koleksi-koleksi wayang terbarunya, juga wayang-wayang lama yang dirawatnya memberikan pandangan tersendiri bagi pengamat wayang dalam memberikan penilaian terhadap subjek. Tanpa pemenuhan kebutuhan ini, subjek tidak akan memiliki dukungan dan pemikiran yang positif terhadap dirinya sebagai seorang dalang. Akhirnya pemenuhan kebutuhan ini mendorong subjek pada perilaku pencapaian kebutuhan selanjutnya yaitu kebutuhan harga diri yang berorientasi pada pencapaian tujuan. 
Berdasarkan uraian di atas maka subjek telah mencapai tingkat pemenuhan kebutuhan yang keempat yaitu kebutuhan akan harga diri. Maslow (1994: 55) membagi kebutuhan akan rasa harga diri menjadi dua, yakni rasa menghargai diri sendiri dan pengakuan dari orang lain. Pada uraian sebelumnya, pemenuhan kebutuhan rasa cinta dan rasa memiliki ternyata memberikan timbal balik berupa dukungan dan prestis yang baik atas subjek. Telah diketahui pula bahwa bakat dan kemampuan subjek mendalang, juga rasa percaya diri yang besar telah dinilai oleh dalang lain sejak awal karir subjek. Ia memiliki banyak dukungan dari dalang-dalang senior yang mengajarinya bermimpi menjadi dalang besar yang diminati masyarakat. Hal tersebut memotivasi subjek untuk mencapai prestis yang tinggi. Ia diajarkan bagaimana menjadi dalang yang mahal karena kualitas. Keadaan subjek sebagai dalang bertarif mahal dan memiliki frekuensi pertunjukan tinggi membuktikan bahwa ia diakui di masyarakat.

Pengakuan masyarakat atas diri subjek bukan berarti ia juga memiliki dukungan penuh dari seniman lain di daerah yang sama. Justru keadaannya sebagai dalang yang diingini masyarakat bisa jadi menimbulkan kebencian dari seniman lain yang tidak satu pikiran dengannya. Banyak olokan atau kritik tajam yang sampai ke telinga subjek, namun baginya hal tersebut tidak mempengaruhinya dalam mewujudkan impiannya. Pengakuan terpenting bagi subjek adalah masyarakat sendiri, sehingga timbulnya cemooh atau ejekan yang terjadi tidak dihiraukan oleh subjek. Ia cukup berkonsentrasi pada kualitas pergelaran dan respon dari orangorang yang menontonnya. Di sisi lain, ia justru mendapatkan banyak dukungan dari seniman luar daerah. Mereka menghormati subjek dan memiliki hubungan yang dekat dengannya. Para seniman dalang di daerah lain justru melihat pertunjukan subjek secara utuh saat digelar di daerah mereka. Di daerah lain, subjek justru memiliki banyak dukungan dari dalang-dalang senior maupun dalang-dalang yang sedang populer di jaman sekarang. Bagi subjek, keberadaannya mendapat pengakuan dari masyarakat dan penggemar di Yogyakarta sudah cukup memberi semangat untuk bermimpi. Informan sesama dalang memberitahukan bahwa subjek dibicarakan justru karena diakui keberadaannya. Ia mengatakan, tidak ada dalang di Yogyakarta yang tidak tahu bahwa subjek adalah dalang laris saat ini.

Maslow (1994: 56) juga menuliskan bahwa pemenuhan akan kebutuhan ini membawa perasaan percaya pada diri sendiri, juga pada nilai, dan kekuatan. Namun rintangan menuju pemenuhan kebutuhan ini akan menimbulkan perasaan rendah diri, lemah, dan tak berdaya. Dalam memenuhi kebutuhan akan rasa harga diri, subjek memiliki beberapa rintangan yang harus dilalui. Cemooh dari orang lain, juga isu yang tersebar terkait mengenai tarif subjek cukup menjadi batu sandungan untuknya dalam memenuhi kebutuhan ini. Rintangan ini memang menimbulkan perasaan rendah diri atau lemah yang sesaat. Hal tersebut kemudian menjadi kekuatan bagi diri subjek untuk bangkit dan kembali melangkah memenuhi kebutuhannya. Harga diri subjek adalah prestasi bagi nya. Tercapainya pemenuhan kebutuhan akan harga diri yang diakui oleh orang lain dan masyarakat, membuktikan bahwa subjek mampu menghargai dirinya sendiri dan memiliki kemampuan lebih untuk mengolah potensi dalam diri. Kemampuan subjek dalam memenuhi kebutuhan akan harga diri ini memacu subjek untuk melanjutkan langkahnya dalam mewujudkan impian.

Puncak dari tingkat pemenuhan kebutuhan dalam teori Maslow adalah kebutuhan akan aktualisasi diri. Maslow (1994: 163) mengungkapkan, orang yang berada pada tingkat perkembangan motivasional aktualisasi diri, dapat dikatakan tindakan dan kreasi mereka sangat spontan, penuh siasat terbuka, membeberkan diri dan disertai pertimbangan. Pemenuhan kebutuhan ini dituangkan subjek sepenuhnya di atas panggung pertunjukan. Subjek membaca masyarakat dan membuat strategi pergelaran yang pas agar kembali dinantikan oleh masyarakat. Kreatifitas dan spontanitas subjek dalam merancang pergelarannya menjadi bagian dari cara memenuhi kebutuhan akan aktualisasi diri. Di atas panggung pertunjukan wayang, seluruh bakat dan kemampuan subjek digelar, diperlihatkan, dan dirasakan oleh orang banyak. Di situlah penonton dapat menilai cara subjek menuangkan potensi dalam diri. Potensi yang dimaksud bukan sekedar bakat dalam mendalang melainkan juga berupa sikap-sikap dalang menghadapi situasi. Subjek berhasil memberikan sajian kepada penonton yang beragam. Ada penonton yang menyukai tingkah 
laku subjek dan spontanitasnya di atas panggung, ada yang menyukai suara dari sindhen favorit yang hanya dapat ditonton melalui pertunjukan subjek, ada pula yang menyukai suara subjek saat melantunkan suluk, atau saat subjek memberikan unsur humor dan kritik sosial dalam adegan, juga mengenai perancangan cerita yang digelarnya. Aktualisasi diri subjek bukan sekedar terlihat pada pertunjukan, namun juga perancangannya. Subjek memperhitungkan kualitas setiap unsur pertunjukan seperti soundsystem dan panggung, termasuk kualitas personil pertunjukan yang bukan sekedar pada bakat namun lebih pada sikap. Rupa-rupanya subjek sangat berstrategi dan mempertimbangkan perbuatan dan akibat yang ditimbulkan setiap ia menggelar pertunjukan wayang. Kesuksesan pentas dan reaksi penggemar menyukai pergelarannya adalah tujuan utama subjek.

Aktualisasi diri diperoleh subjek berdasarkan kesadaran akan bakat yang dimilikinya. Sebelum ayahnya meninggal, mendalang hanyalah kegemaran baginya. Namun sesudah itu, mendalang bukan sekedar penyaluran bakat dan potensinya namun juga sebagai alat subjek memenuhi setiap tingkat kebutuhan. Dengan penyaluran bakat sebagai alat pemenuhan seluruh tingkat kebutuhan, subjek berhasil mengaktualisasikan diri dan meraih impiannya. Hal tersebut sejalan dengan pemikiran Maslow (1994: 164) mengenai perwujudan diri atau aktualisasi diri. Dikatakan olehnya bahwa potensi diri merupakan sesuatu yang tumbuh dari dalam, dari sesuatu yang telah ada dalam organisme itu, atau lebih tepat lagi, dari sesuatu yang merupakan organisme itu sendiri. Tanpa penuangan bakat sebagai landasan pemenuhan kebutuhan, maka seseorang akan mengalami kesulitan yang lebih atau bisa jadi membutuhkan waktu lama untuk mencapai tahap aktualisasi diri.

\section{Piramida Pemenuhan Kebutuhan Ki Seno Nugroho}

Maslow (1994: 164) mengungkapkan, aktualisasi diri lebih bermotivasi pada pertumbuhan bukan kekurangan. Orang yang mencoba mengaktualisasikan diri akan memecahkan persoalan motivasional kecil, dengan demikian mereka akan menyadari dan dapat menghadapi dengan spontanitasnya. Dalam mengatasi permasalahan, mereka lebih memilih untuk terus mencoba dari pada tidak mencoba. Aktualisasi diri Ki Seno Nugroho terwujud berdasarkan proses pemenuhan kebutuhan bertingkat. Tentang hal ini dapat dibaca dalam analisis pemenuhan kebutuhan subjek di atas. Telah dibahas sebelumnya bahwa subjek sempat tidak berkeinginan menjadi dalang seperti ayahnya. Namun seiring berjalannya waktu, ketertarikannya pada wayang mulai dipahaminya sebagai bakatnya karena diturunkan oleh ayah, kakek, dan generasi terdahulu. Subjek menyadari bakatnya setelah ia menonton pertunjukan wayang dengan gerak sabet Ki Manteb Soedarsono. Beberapa tahun setelah ia mulai menekuni bakatnya, ayahnya meninggal dunia. Pada saat itu perjuangan subjek memulai proses pemenuhan kebutuhan mulai terlihat dengan jelas. Keadaan perekonomian membuatnya harus berjuang memiliki pekerjaan tetap. Mulai saat itu subjek bermimpi untuk menjadi dalang seperti pesan Ki Sofyan yang pernah diutarakan kepadanya. Setelah subjek bermimpi maka ia akan berjuang untuk mewujudkannya. Jika subjek mampu menjadi dalang yang bertarif mahal dan digemari masyarakat maka seluruh kebutuhan hidupnya terlalui. Artinya, puncak kebutuhan subjek akan dicapai melalui beberapa proses yang dikelompokkan Maslow ke dalam lima tingkat kebutuhan yaitu: (1) kebutuhan dasar fisiologis, (2) kebutuhan akan keselamatan, (3) Kebutuhan akan cinta dan rasa memiliki, (4) kebutuhan akan harga diri, (5) kebutuhan akan aktualisasi diri. Jika digambarkan maka lima tingkat kebutuhan Maslow dalam dilihat dalam gambar 1 .

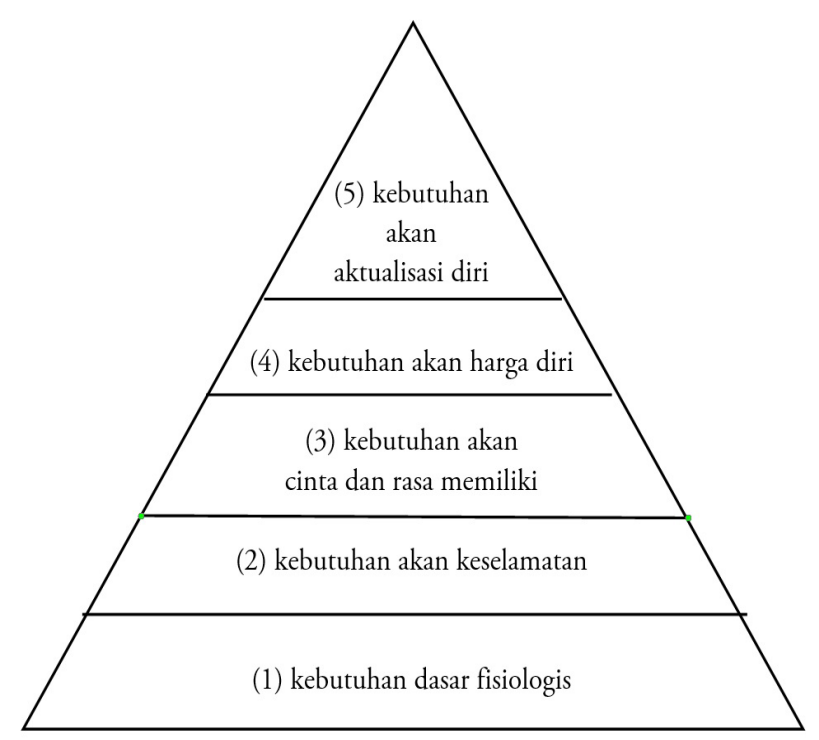

Gambar 1. Piramida pemenuhan kebutuhan Maslov. 
Proses pemenuhan kebutuhan Seno Nugroho hingga mencapai puncak dapat diuraikan sebagai berikut. Pertama; subjek harus memenuhi kebutuhan dasar fisiologisnya (kebutuhan untuk kesenangan panca indranya), ia berpuasa, melatih diri, menonton pertunjukan wayang, merokok, mewujudkan rumah pribadi dengan segala properti yang ada di dalamnya, dan kesenangan indrawi lainnya dengan memiliki penghasilan yang cukup. Kedua; subjek menghindarkan dirinya dari berbagai ancaman yang mengganggu pemenuhan kebutuhannya. Ia berhasil memiliki pekerjaan tetap. Kemudian, ia berhasil memiliki banyak penggemar sehingga ia dapat bertahan mendalang karena diinginkan masyarakat. Ketiga; setelah kebutuhan dasar fisiologis dan rasa aman terpenuhi subjek mulai menyadari bahwa ia harus menuangkan rasa cinta dan sosialnya kepada orang lain maupun pada barang-barang kegemarannya. Ia menuangkan rasa cinta dan rasa memiliki kepada keluarga, kerabat, tim kerja, lingkungan tetangga, kelompok penggemar, juga pada wayang-wayang koleksi pribadinya. Pada akhirnya pemenuhan kebutuhan ini menimbulkan dukungan balik kepada subjek saat ia harus memenuhi kebutuhannya mendalang dan mencapai impiannya. Keempat; tanpa disadari perbuatan subjek memenuhi tiga tingkat kebutuhan sebelumnya (kebutuhan tingkat tiga) telah melahirkan penilaian positif dari orang lain. Pada tahap ini, subjek harus mendapatkan lebih banyak pengakuan dari orang lain sehingga tingkat kebutuhan ini terpenuhi. Oleh karena itu dibutuhkan kepercayaan yang tinggi terhadap kemampuan yang dimiliki, sehingga ia mendapatkan pengakuan dari orang lain. Dalam tahap ini, subjek telah berhasil bertahan melewati rintangan yang merusak harga diri subjek. Kebertahanan subjek menghadapi cemooh maupun isu yang tersebar membuktikan sikap menghargai diri sendiri yang kuat. Artinya, subjek mampu memenuhi kebutuhan tingkat selanjutnya. Kelima; subjek akan menuangkan seluruh potensi diri di atas panggung pertunjukan pergelaran wayang. Perkembangan pertunjukan subjek adalah gambaran dari penuangan bakat dan pencapaian proses tahap demi tahap. Wujud pakeliran subjek saat ini merupakan hasil dari proses pakeliran sebelumnya yang ia kembangkan selama kurang lebih 20 tahun dengan mempertimbangkan selera penggemar. Pada akhirnya, aktualisasi diri subjek didapatkan berdasarkan sikap subjek dalam memenuhi kebutuhannya, dengan demikian impian subjek berhasil tercapai. Berdasarkan ulasan tersebut, subjek telah mencapai kebutuhan aktualisasi diri melalui pemenuhan tingkatan kebutuhan dalam piramida yang dikategorikan oleh Maslow. Jika dilihat kembali mengenai cara subjek menghadapi permasalahan dan memenuhi kebutuhannya tahap demi tahap, dapat diketahui bahwa impian menjadi dalang yang bertarif tinggi dan diminati masyarakat adalah bekal subjek untuk dapat berproses memenuhi setiap tingkat kebutuhan dan mengaktualisasikan dirinya. Mengikuti piramida pemenuhan kebutuhan yang dibangun oleh Maslow, tahap-tahap pemenuhan kebutuhan Ki Seno Nugroho hingga mencapai puncak pemenuhan kebutuhan dapat dilihat dalam gambar 2.

Maslow (1994: 31) berasumsi bahwa manusia tidak berhenti pada satu keinginan, demikian pula subjek yang telah mencapai impian akan kembali berkeinginan mempertahankan mimpinya. Subjek masih memiliki keinginan yang belum terwujud yaitu membangun sanggar lengkap dengan kelir dan gamelan sehingga dapat digunakan sebagai tempat pelatihan mendalang. Mimpi terbesar subjek adalah pertunjukan wayang yang terus berlanjut dan dilestarikan dari generasi ke generasi. Oleh karena itu, subjek berharap anaknya juga turut berperan dalam mewujudkan mimpi terbesarnya itu.

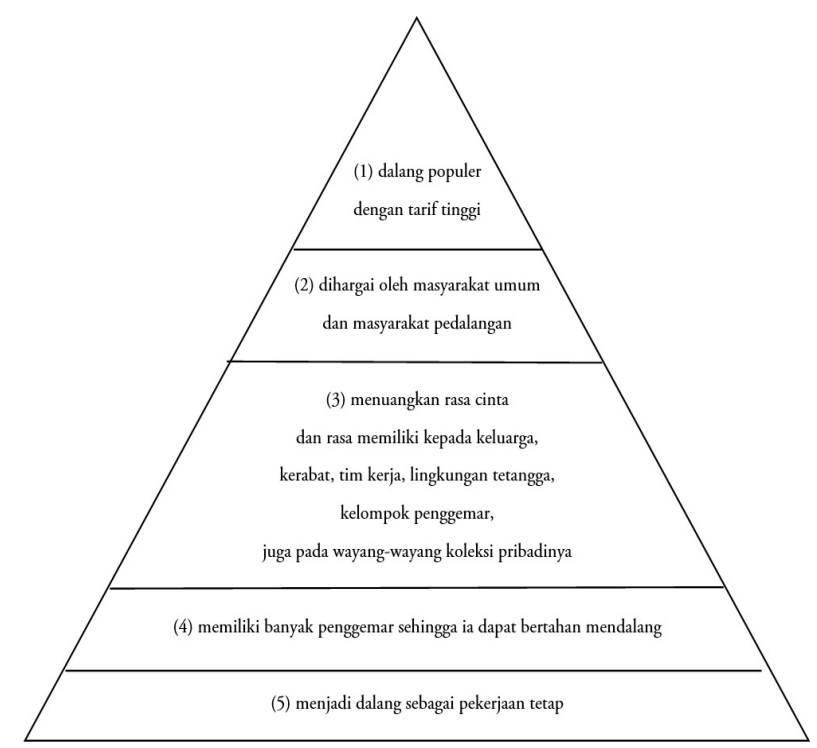

Gambar 2. Piramida pemenuhan kebutuhan Ki Seno Nugroho. 


\section{Penutup}

Berdasarkan hasil pelacakan terhadap tahaptahap atau proses yang dilalui Ki Seno Nugroho dapat dikatakan bahwa menjadi dalang kondhang dan laris (baca: dalang popular dengan tarif tinggi) merupakan wujud dari aktualisasi diri Ki Seno Nugroho yang merupakan puncak dari proses pemenuhan setiap tingkat kebutuhan. Dari pelacakan terhadap aktualisasi diri Seno Nugroho, kiranya kita dapat belajar bahwa seseorang jika ingin mencapai puncak kebutuhan tertinggi harus menyadari bakat potensi yang ada dalam dirinya. Bakat dan potensi dalam diri tersebut akan melahirkan impian sebagai kebutuhan tertinggi. Impian tersebut akan terwujud sesuai dengan usaha yang dilakukan untuk memenuhi setiap tingkat kebutuhan.

Ki Seno Nugroho telah membuktikan dirinya mampu mengaktualisasikan diri menjadi dalang yang diminati masyarakat. Ia mengolah bakat yang dimiliki sebagai modal untuk memenuhi kebutuhan dasar fisiologis, kebutuhan akan rasa aman, kebutuhan akan rasa cinta dan memiliki, kebutuhan akan rasa harga diri dan kebutuhan akan aktualisasi diri. Proses menuju tingkat kebutuhan aktualisasi diri diraih berawal dari satu impian dan keberhasilan mencapainya. Ternyata proses pemenuhan piramida kebutuhan tidak berhenti pada satu impian saja. Orang yang telah mencapai tingkat kebutuhan aktualisasi diri akan mempertahankan mimpi yang telah diraih dan menciptakan mimpi-mimpi selanjutnya. Ki Seno Nugroho sebagai dalang telah mampu mencapai tingkat aktualisasi diri, namun ia masih memiliki impian selanjutnya. Ia ingin mempertahankan penggemar, selain itu ia juga menginginkan agar pergelaran wayang dilestarikan pula oleh generasi berikutnya. Hal tersebut belum dapat dilihat melalui penelitian ini, melainkan melalui penelitian selanjutnya. Oleh karena itu, aktualisasi Ki Seno Nugroho perlu diteliti kembali seiring dengan perjalanannya mencapai impian selanjutnya. Penelitian ini merupakan pemikiran dasar yang dilakukan secara singkat mengenai proses $\mathrm{Ki}$ Seno Nugroho mencapai impian masa mudanya menjadi dalang 'payu dan laris' (bertarif tinggi dan diminati). Kemampuan dalam mengolah bakat dan berproses menghadapi rintangan berikutnya akan memberikan pemikiran baru mengenai aktualisasi diri Ki Seno Nugroho.

Melihat keinginan Ki Seno Nugroho untuk mempertahankan penggemar dan mempertahankan pergelaran wayang agar terus dilestarikan, maka piramida kebutuhan Maslow tidak sekedar berjalan pada satu tahap pencapaian dari tingkat dasar menuju tingkat puncak. Pemenuhan setiap tingkat kebutuhan akan terus berlangsung sesuai dengan perkembangan individu dalam kemampuannya menghadapi rintangan kehidupan. Individu akan dapat bertahan pada kebutuhan aktualisasi diri, jika ia memiliki sikap-sikap khusus yang membuatnya mampu bertahan. Sebaliknya ia akan kembali pada tingkat pemenuhan kebutuhan sebelumnya jika ia tidak mampu mempertahankannya.

Berdasarkan hasil analisis mengenai aktualisasi diri Ki Seno Nugroho di depan, diperoleh suatu pandangan bahwa seorang dalang dapat mencapai aktualisasi diri melalui proses pemenuhan setiap tingkat kebutuhan. Ki Seno Nuroho sebagai subjek penelitian ini adalah dalang yang usianya belum mencapai setengah abad, sehingga perjalanan karir untuk memenuhi kebutuhan aktualisasi diri masih panjang. Masih banyak masalah-masalah selanjutnya yang dapat diteliti mengenai motivasi Ki Seno Nugroho.

Ada beberapa hal yang belum dilakukan dalam penelitian misalnya ketika berbicara mengenai kehidupan seorang dalang, seharusnya peneliti juga melihat karya-karyanya, sementara peneliti hanya berhenti pada wawancara dan pengamatan terhadap diri subjek. Padahal ketika berbicara tentang dalang berarti juga harus mempelajari sikap dan pemikiran dalang melalui karya-karyanya.

Akhirnya dapat disimpulkan bahwa penelitian dengan pendekatan psikologis sangat dipengaruhi oleh pengalaman hidup peneliti. Artinya peneliti setidak-tidaknya harus menjadi insider dalam waktu yang cukup lama dalam dunia kehidupan seorang dalang dan karya-karyanya. Dengan demikian, pemetaan pemenuhan kebutuhan melalui karya dan perilaku dalang akan lebih komprehensif.

\section{Kepustakaan}

Ahimsa, Heddy Shri. 2000. Ketika Orang Jawa Nyeni. Yogyakarta: Galang Press.

Cofer, C.N, Appley. 1964. Motivation: Theory and 
Research. New York: Wiley and Sons.

Groenendael, Victtoria M. 1987. Dalang Di Balik Wayang. Jakarta: Grafiti press.

Kasidi, dkk. 1998. Inovasi \& Transformasi Wayang Kulit. Yogyakarta: Lembaga Studi Jawa.

Kayam, Umar. 2001. Kelir Tanpa Batas. Yogyakarta: Gama Media.

Koeswara, E. 1995. Motivasi, Teori dan Penelitiannya. Bandung: Angkasa.

Kurniawan, Ari, S. Lestari, dan R. Martha. 2015. Efektivitas Teknik Paper Seminar untuk Mengajar Menulis Ditinjau dari Aktualisasi Diri Mahasiswa. Jurnal LPPM Vol.3 No.1 Januari 2015, hal 307-319. Madiun: IKIP PGRI.

Maslow, A. H. 1968. Toward a Psychology of Being, 2nd ed. New York: Van Nostrand Reinhold. . 1994. Motivasi dan Kepribadian jilid I: Teori Motivasi dengan pendekatan Hierarki Kebutuhan Manusia terjemahan dari judul asli Motivation and Personality. Diindonesiakan Nurul Imam. Jakarta: PT Pustaka Binaman Pressindo.

Murtiyasa, Bambang. 1995. Faktor-faktorPendukung Popularitas Dalang. Tesis. Yogyakarta: Program Studi Pengkajian Seni Pertunjukan PascaSarjana UGM.

Nugroho, Agung. 1996. Catatan Sekilas tentang Dalang Ki Seno Nugroho. Manuskrip. Koleksi Agung Nugroho.

Sondang, P. Siagian. 2012. Teori Motivasi dan Aplikasinya. Jakarta: Rineka Cipta.

Sudarwan, Danim. 2012. Motivasi Kepemimpinan \& Efektifitas Kelompok. Jakarta: Rineka
Cipta.

Sunarto. 2009. Wayang Kulit Purwa, dalam Pandangan Sosio-Budaya. Yogyakarta: Arindo Nusa Media.

Suwondo. 2001. "Suharni Sabdowati Dalang Penganut Gaya Nartasabda”. Tesis. Program Studi S2 Pengkajian Seni Pertunjukan dan Seni Rupa Jurusan Ilmu Humaniora. Yogyakarta: UGM.

Wahjosumidjo. 1987. Kepemimpinan dan Motivasi. Jakarta: Gahlia Aksara.

Yudiarti, Sri Indriatmi. 2010. Wayang Mbeling Kreativitas Dalang sebagai Komunikasi Sosial. Gelar Jurnal Seni dan Budaya. Vol.8 No.1 Juli 2010, hal 122-133. Surakarta: ISI Surakarta

Yulianus, Raden, 1999. Motivasi Kerja Buruh Gendong dalam Meningkatkan Ketahanan Keluarga, (Studi Penelitian di Pasar Beringharjo Kodya Yogyakarta DIY). Tesis. Program Studi S2 Ketahanan Nasional. Yogyakarta: UGM.

\section{Webtografi}

http://kiSenojogja.blogspot.co.id/2013_06_01_ archive.html. Diakses pada tanggal 14 Desember 2015 pukul 13.30 WIB.

http://www.brilio.net/news/ki-Seno-nugrohodalang-jogja-yang-sukses-meniti-karir-di-luarnegeri-150425z.html. Diakses pada tanggal 14 Desember 2015 pukul 15.26 WIB.

Akun PWKS (Pecinta Wayang Ki Seno Nugroho) dalam Grup Facebook (Sosial Media). Pantauan berkala pada bulan Agustus 2015Januari 2016. 